\title{
AVALIAÇÃO E HIERARQUIZAÇÃO DA FRAGILIDADE DOS SOLOS DO NOROESTE DO ESTADO DO PARANÁ ${ }^{1}$
}

\begin{abstract}
Laiane Ady Westphalen²
A avaliação e a hierarquização da fragilidade solos à erosão, considerando suas características físicas e morfológicas, pode contribuir significativamente para estudos ambientais. Com intuito de mapear e fornecer auxílio à compreensão e solução dos problemas relacionados aos solos do Estado do Paraná, a Empresa Brasileira de Pesquisa Agropecuária - EMBRAPA elaborou um documento que apresenta detalhadamente as propriedades morfológicas, físicas, químicas e mineralógicas de perfis de solos do Estado. As informações apresentadas fornecem subsídios para avaliação dos solos e, por extrapolação, permitem propor uma classificação hierárquica destes de acordo com o grau de fragilidade a erosão. Para o levantamento das informações, a EMBRAPA dividiu o Estado em onze áreas de estudo, sendo selecionada para a presente pesquisa a área I, que abrange a porção Noroeste. Conforme dados da Minerais do Paraná S.A MINEROPAR (2005 p. 57), a área é composta, predominantemente, por rochas areníticas de textura fina a média da Formação Caiuá, originando solos de textura arenosa, propícios a erosão. O processo de ocupação desencadeou-se a partir da década de 1940, em função da expansão da agricultura cafeeira, acarretando na retirada da vegetação e intensificação dos processos erosivos. Tais processos são de difícil controle e recuperação, promovendo a degradação e perda de produtividade dos solos e assoreamento dos rios. (IPARDES, 2004 p. 14; PONTES, 1977 p.14). Por fim, baseando-se nos trabalhos desenvolvidos, pretende-se analisar as informações físicas e morfológicas dos solos, que abrangem o Noroeste do Estado, e classificar a fragilidade destes à erosão. Dada a dimensão da área de estudo, as informações desenvolvidas pela EMBRAPA, serão fundamentais para realização do trabalho. Cabe ressaltar que a presente pesquisa está atrelada a um projeto maior, cujo objetivo é mapear a Fragilidade Ambiental do Estado, desenvolvido entre o Laboratório de Hidrologia e Geomorfologia (LHG) do Departamento de Geografia e a MINEROPAR.
\end{abstract}

PALAVRAS-CHAVE: fragilidade; erosão; noroeste do Estado

\footnotetext{
${ }^{1}$ Orientador: Prof. Dr. Leonardo José Cordeiro Santos

2 Mestranda em Geografia (UFPR) - e-mail: laianeaw@yahoo.com.br
} 